\title{
Correction: Exploiting the promiscuity of imatinib
}

Shun J Lee ${ }^{* 1,2}$ and Jean YJ Wang 1,2,3

An error in the PDB code occurred in the article published in the Journal of Biology [1]. In the legend to Figure One, instead of 1FW3, the correct PDB code is 3FW1.

\section{Author Details}

'Department of Medicine and Division of Hematology-Oncology, School of Medicine, University of California, San Diego, La Jolla, CA 92093, USA, 2Moores Cancer Center, 3855 Health Sciences Drive, University of California, San Diego, La Jolla, CA 92093-0820, USA and 'Bivision of Biological Sciences, University of California, San Diego, La Jolla, CA 92093, USA

Received: 10 June 2010 Accepted: 10 June 2010

Published: 10 June 2010

\section{References}

1. Lee SJ, Wang JYJ: Exploiting the promiscuity of imatinib. Journal of Biology 2009, 8:30

doi: 10.1186/1741-7007-8-82

Cite this article as: Lee and Wang, Correction: Exploiting the promiscuity of imatinib BMC Biology 2010, 8:82

* Correspondence: jywang@ucsd.edu

${ }^{1}$ Department of Medicine and Division of Hematology-Oncology, School of Medicine, University of California, San Diego, La Jolla, CA 92093, USA

Full list of author information is available at the end of the article
Submit your next manuscript to BioMed Central and take full advantage of:

- Convenient online submission

- Thorough peer review

- No space constraints or color figure charges

- Immediate publication on acceptance

- Inclusion in PubMed, CAS, Scopus and Google Scholar

- Research which is freely available for redistribution

Submit your manuscript at www.biomedcentral.com/submit

() 2010 Lee and Wang; licensee BioMed Central Ltd. This is an Open Access article distributed under the terms of the Creative Commons BHW Central Attribution License (http://creativecommons.org/licenses/by/2.0), which permits unrestricted use, distribution, and reproduction in any medium, provided the original work is properly cited. 